\title{
KONTRIBUSI PERUSAHAAN PULP AND PAPER SERANG BAGI KEHIDUPAN MASYARAKAT DAN PEMERINTAH DAERAH
}

\author{
Aryanti Puspokusumo \\ Jurusan Manajemen, Fakultas Ekonomi dan Bisnis, Universitas Bina Nusantara, \\ Jln. K.H. Syahdan No. 9, Palmerah, Jakarta Barat 11480
}

\begin{abstract}
The purpose of this study is to determine what contributions are provided by PT Indah Kiat Plup and Paper Tbk Serang Mill on the community and local government through the participation of Public Relation, especially in terms of education. The study is conducted from September 2009 until February 2010. The results showed that the community around the company has a large and direct impact on overall corporate performance. Community economic development in terms of education is a part of a Community Relation program conducted by the firm and has provided benefits to the community. Some suggestions for input to the company, includes optimizing the use of internal media organizations, granting broader authority for Public Relation so that they can better support the performance and needs of the company
\end{abstract}

Keywords: Serang community, community relation, public relation

\begin{abstract}
ABSTRAK
Tujuan dari penelitian ini adalah untuk mengetahui Kontribusi apa saja yang sudah diberikan oleh PT Indah Kiat Plup and Paper Tbk Serang Mill terhadap masyarakat dan pemerintah daerah melalui peran serta Public Relation, khususnya dalam hal pendidikan. Penelitian ini dilakukan mulai September 2009 sampai Februari 2010. Hasil penelitian menunjukkan bahwa komunitas sekitar perusahaan memiliki pengaruh besar dan langsung pada kinerja perusahaan secara keseluruhan. Pengembangan ekonomi komunitas dalam hal Pendidikan, merupakan program Community Relation yang dilakukan oleh perusahaan dan telah memberikan manfaat bagi masyarakat sekitar. Beberapa saran yang bisa menjadi masukan bagi perusahaan, yaitu pengoptimalan penggunaan media internal organisasi, pemberian kewenangan yang lebih luas bagi Public Relation sehingga bisa lebih mendukung kinerja dan kebutuhan dari perusahaan.
\end{abstract}

Kata kunci: masyarakat Serang, comminity relation, public relation 


\section{PENDAHULUAN}

PT Indah Kiat Pulp and Paper. Tbk Serang Mill merupakan salah satu perusahaan kertas terbesar di Asia Tenggara dan telah memberikan kontribusi bagi masyarakat sekitar dan Pemerintah Daerah Kabupaten Serang (Kecamatan Kragilan). Kontribusi-kontribusi yang diberikan antara lain bidang Pendidikan, Agama, Sosial Kemasyarakatan, Kemitraan, Tenaga kerja, dan Kesehatan. Kehadiran PT Indah Kiat Pulp and Paper. Tbk Serang Mill di tengah-tengah masyarakat memberikan peluang kerja maupun peluang usaha bagi masyarakat sekitar lingkungan pabrik. Dengan demikian, kehadirannya di Kabupaten Serang (Kecamatan Kragilan) inipun membantu pemerintah untuk menaikkan strata kehidupan pada masyarakat dan juga menambah pendapatan daerah tersebut.

Setiap perusahaan pasti mempunyai permasalahan-permasalahan sendiri dalam menghadapi masyarakat sekitar. Seperti yang dihadapi oleh PT Indah Kiat Pulp and Paper Tbk Serang Mill, di mana ada beberapa masyarakat yang tidak paham tentang pentingnya keberadaan perusahaan dalam menunjang ekonomi daerah. Beberapa contoh penghargaan yang didapat, antara lain (1) Piagam Penghargaan Pendidikan (beasiswa GNOTA) yang diberikan oleh Kabupaten Serang, (2) ISO 14001 (Sistem Manajemen Lingkungan) yang diberikan oleh SGS Indonesia, dan (3) PROPER (Program Penilaian Kerja Perusahaan) peringkat biru yang diberikan oleh Menteri Lingkungan Hidup. Kontribusi-kontribusi yang diberikan merupakan kerja keras departemen Humas selaku departemen yang menjalankan program-program bagi masyarakat sekitar. Departemen Humas merupakan salah satu aspek manajemen yang diperlukan oleh setiap perusahaan. Kehadiran departemen Humas merupakan salah satu elemen yang menentukan kelangsungan suatu perusahaan secara positif. Humas atau Public Relation mencakup semua bentuk komunikasi yang terselengggara antara perusahaan yang bersangkutan dengan siapa saja yang memiliki kerjasama dengan perusahaan tersebut.

Publik merupakan kekuatan yang sangat besar yang bisa berpengaruh langsung maupun tidak langsung terhadap kondisi perusahaan. Komunikasi yang baik antara perusahaan dengan publik sangat penting untuk menciptakan lingkungan sosial yang harmonis. Salah satu cara untuk membangun image positif di mata masyarakat atau publik adalah menjalankan kegiatan eksternal untuk mendukung lancarnya perusahaan. Community Development \& Community Relation adalah salah satu program eksternal yang berupaya untuk menjalin hubungan komunikasi yang baik dengan komunitas atau masyarakat sekitar. Setiap bulan dana Social Responsibility yang diperoleh dari karyawan, akan diberikan kepada setiap siswa yang tidak mampu dan para siswa yang berprestasi pada tiap semester, Perusahaan menyalurkan bantuan beasiswa Gerakan Nasional Orang Tua Asuh (GNOTA) untuk anak-anak yang tidak mampu dan memberikan bantuan fasilitas pendidikan, memberikan bantuan berupa buku-buku pelajaran dan buku cetak kepada setiap siswa-siswi dan memberikan bantuan musibah bencana alam dan semuanya itu merupakan bantuan untuk kemanusiaan yang pernah dibantu oleh tim Social Responsibility. Kegiatan penyaluran bantuan tersebut diberikan secara langsung oleh tim Social Responsibility perusahaan.

Berdasarkan uraian dalam latar belakang penelitian tersebut diatas, maka yang menjadi pokok perumusan masalah dalam penelitian ini adalah: Kontribusi PT Indah Kiat Pulp and Paper Tbk Serang Mill bagi kehidupan masyarakat dan pemerintah daerah melalui peran serta Public Relation.

Tujuan penelitian ini antara lain untuk (1) Mengetahui aktifitas beberapa program kegiatan Public Relation untuk menunjang program image builder bagi perusahaan; (2) Mengetahui secara langsung kegiatan Communication Relation yang dijalankan oleh perusahaan; (3) Melihat, mengamati, mempelajari dan mengetahui secara langsung kegiatan image builder dalam menjalankan secara langsung kegiatan Public Relation Departement dalam menjalankan perannya di PT Indah Kiat Plup \& Paper Tbk Serang Mill; (4) Mengetahui implementasi kinerja Public Relation dalam pengembangan citra perusahaan; (5) Mengetahui kontribusi apa yang sudah diberikan kepada masyarakat dan 
pemerintah daerah melalui peran serta Public Relation; (6) Mengetahui kendala-kendala apa saja yang dihadapi perusahaan dalam memberikan kontribusi-kontribusi kepada masyarakat sekitar; (7) Mengetahui solusi-solusi apa saja yang diambil perusahaan dalam menghadapi masyarakat sekitar melalui peran serta Public Relation, 8) dan bagaimana tanggapan dari masyarakat terhadap keberadaan PT Indah Kiat Pulp and Paper Tbk Serang Mill.

Proses kerja Public Relation. Iriantara (2006:9) mengemukakan bahwa proses Public Relation adalah sebagai kegiatan komunikasi yang dijalankan organisasi, sedangkan Kensali (1988:82-85) mengutip, menurut Cutlip dan Center menyebutkan bahwa proses Public Relation terdiri dari 5 hal, yaitu pengumpulan data, definisi permasalahan, perencanaan, aksi dan komunikasi serta evaluasi (Sumber: Rhenald Kesali). Citra (Image). Anggoro (2001:62) mengemukakan beberapa jenis citra, yakni citra bayangan (mirror image), citra yang berlaku (current image), citra harapan (wish image), citra perusahaan (corporate image), dan citra majemuk (multiple image). Dalam suatu organisasi, citra yang digunakan adalah citra perusahaan (corporate image) yang memiliki definisi sebagai "citra dari suatu organisasi secara keseluruhan“. Menurut Ruslan (1994:66), pengertian citra itu sendiri abstrak (intangible), tetapi wujudnya bisa dirasakan dari penilaian, baik semacam tanda respek dan rasa hormat, dari publik sekelilingnya atau masyarakat luas terhadap perusahaan. Citra kata yang terdiri dari 5 huruf ini menurut Lawrence L. Steinmetz, penulis buku Managing Small Business mengartikan citra sebagai "Pancaran atau reproduksi jati diri atau bentuk perorangan, benda atau organisasi". Menurut Lawrence, bagi perusahaan citra juga dapat diartikan sebagai prepsepsi masyarakat terhadap jati diri perusahaan (Sutojo, 2004:1).

Citra menurut Kotler (2005:553) adalah "Image is the set of beliefs, ideas, and impressions a person hold regarding an object. People attitudes and actions toward an object are highly conditioned by that objective image". Maksudnya adalah citra mengambarkan suatu objek tertentu, sikap dan tindakan seseorang terhadap suatu objek akan ditentukan oleh citra objek tertentu. Soemitro dan Ardianto (2004:111-114) mengemukakan citra sebagai cara bagaimana pihak lain memandang sebuah perusahaan, seseorang, suatu komite atau aktivitas. Alifami (2005:72) mengutip ungkapan yang dikemukakan Joe Marconi dalam buku Image Marketing: using Public perception to Attain Business Objectives (1997). Ada ungkapan yang berbunyi "Picture is a Thousand Words", gambaran mengungkapkan seribu kata. Artinya adalah sebuah gambaran mengandung begitu banyak makna. Akan tetapi, ada ungkapan yang berlawanan, "when a word a worth a thousand pictures, that word has image marketability", yang artinya apabila sebuah kata mampu menerjemahkan seribu gambar berarti kata itu memiliki citra yang bisa dipasarkan.

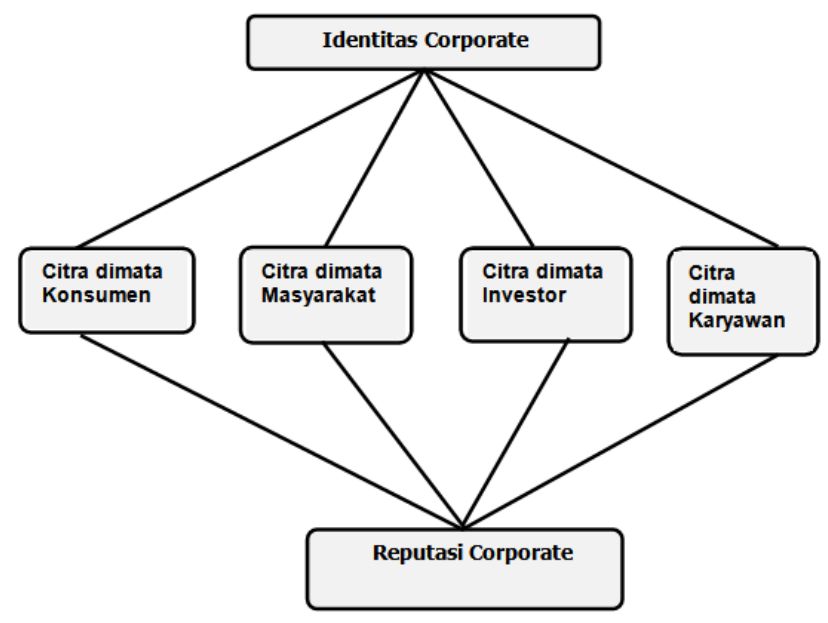

Sumber: Alifahmi

Gambar 1 Dari Identitas Menuju Reputasi 
Alifahmi (2005:134) mengemukakan, Fombrun mengemukakan ada 3 titik penting dalam sebuah citra atau reputasi, yaitu identitas korporat, citra korporat, dan reputasi korporat, di mana identitas korporat sebagai titik pertama yang tercermin melalui nama perusahaan (logo), misalnya laporan tahunan, brosur, kemasaan produk, iklan, pemberitaan media, komunikasi, baik internal perusahaan maupun dalam interaksi dengan pihak luar. Kemudian, identitas korporat tersebut memancarkan citra kepada khalayak atau pihak terkait antara lain citra dimata masyarakat sekitar, investor, dan karyawan sendiri, sehingga jadilah citra korporat, kumpulan citra dibenak khalayak atau publik tersebut membentuk reputasi korporat yang mencerminkan persepsi publik mengenai tindakantindakan perusahaan yang telah berlalu dan prospek perusahaan dimasa mendatang.

Sutojo (2004:3) mengemukakan bahwa citra perusahaan yang baik dan kuat mempunyai beberapa manfaat, yakni sebagai daya saing jangka menegah dan jangka panjang yang menetap (mid and long term sustainable competitive position); menjadi perisai selama krisis (insurance for adverse times); menjadi daya tarik eksekutif handal (attracting for adverse times); meningkatkan efektifitas strategi pemasaran (increasing the effectiveness of marketing instruments); dan penghematan biaya operasional (cost saving). Jadi, citra di sini bukan citra atas produk dan pelayanan saja, citra perusahaan terbentuk oleh banyak hal (hal positif atau hal negatif).

Public Relation selalu menghubungkan organisasi dengan publiknya. Wajar bila kemudian muncul beberapa pertanyaan, “apa atau siapa publik itu?”. Di samping itu, kini sering juga mendengar istilah lain yakni para pihak (stakeholder). Bahkan sering terkesan, stakeholder pun disamakan dengan publik organisasi. Meski tak sama betul antara publik dan para pihak, namun dalam konteks ini kita bisa menyamakan antara publik dan para pihak tersebut. Keduanya sama-sama sebagai pihak yang dilayani dan dijembatani melalui berbagai kegiatan Public Relation. Para pihak, menurut Wheelen dan Hunger (1955:61) adalah kelompok-kelompok yang berkepentingan dengan aktivitas organisasi, dan lantaran berkepentingan, maka kelompok-kelompok tersebut mempengaruhi atau dipengaruhi oleh pencapaiaan tujuan perusahaan. Adapun menurut Rhenald Kasali (1944:63), para pihak adalah "setiap kelompok yang berbeda di dalam maupun luar perusahaan.” Dengan demikian, publik bisa dinyatakan sebagai pihak-pihak yang memiliki kepentingan langsung atau tidak langsung terhadap satu organisasi. Di antara organisasi dan publik terjadi hubungan saling mempengaruhi sehingga terjadi perubahan pada pihak lain. Perubahan selera publik misalnya akan mengubah jenis produk yang dihasilkan satu organisasi.

Rhenald Kasali (1994:11) membagi publik organisasi menjadi 5 bagian, yaitu (1) Publik internal dan publik eksternal. Publik internal adalah publik yang berada di dalam organisasi, seperti karyawan, manajer, dan pemegang saham. Publik eksternal adalah publik yang berada di luar organisasi seperti pemasok dan komunitas; (2) Publik primer, sekunder dan marginal. Dalam kegiatan Public Relation tentunya tidak semua stakeholder akan diterpa oleh pesan- pesan yang disampaikan sehingga disusunlah prioritas. Berdasarkan prioritas itu, maka ditetapkan mana publik primer yang merupakan publik yang paling penting, publik yang kurang penting atau publik sekunder, dan publik yang bisa diabaikan yakni publik marginal; (3) Publik tradisional dan publik masa depan. Publik tradisional adalah publik yang pada saat sekarang sudah berhubungan dengan organisasi seperti karyawan dan pelanggan. Sedangkan publik masa depan adalah publik yang pada masa depan diperkirakan akan memberikan pengaruhnya pada organisasi seperti mahasiswa, peneliti, dan konsumen potensional; (4) Proponents, opponents, dan uncommitted. Di antara publik-publik itu, tentu ada publik yang menentang organisasi (opponents), yang berpihak pada organisasi (proponents) dan publik yang tak peduli (uncommitted); (5) Silent majority dan vocal majority. Dari kalangan publik yang menentang dan memihak organisasi, tentu ada yang menyatakan penentangan atau dukungannya secara vocal, namun ada pula yang menyatakannya secara pasif (silent).

Hubungan antara organisasi dan komunitas bukanlah sekedar soal bertetangga belaka. Bila komunitas dimaknai dengan lokalitas belaka melainkan juga dimaknai secara struktural, artinya dilihat dari aspek interaksi yang pada saat ini bisa saja berlangsung di antara individu yang berbeda 
lokasinya. Masih menurut Daugherty (2003), tanggung jawab sosial itu merupakan perkembangan proses untuk mengevaluasi stakeholder dan tuntutan lingkungan serta implementasi program-program untuk menangani isu-isu sosial. Tanggung jawab sosial itu berkaitan dengan kode etik, sumbangan perusahaan program-program Community Relation dan tindakan mematuhi hukum.

Create Profit Inc (2001) mengambarkan 3 tahapan perkembangan konsep tanggung jawab sosial organisasi bisnis itu dalam konteks Community Relation, yaitu (1) Community Relation dan pemberian sumbangan sebagai respon atas kebutuhan atau tekanan lokal dan manajemen senior / Chief Executive Officer (CEO) pada tahun 1960 dan 1970; (2) Pada tahun 1980 dan 1990 berkembang model Community Relation yang dinamakan "Model Kewarganegaraan Korporat", yang didasarkan pada isuisu etis; (3) Berkembang konsep aliansi strategis yang terkait erat dengan tujuan organisasi yang muncul sejak tahun 1999. Uraian lebih rinci dibuat oleh Waddock dan Boyle (1995) yang menunjukkan dinamika perubahan hubungan antar organisasi, khususnya organisasi bisnis dan komunitas. Keduanya melihat ada pergeseran yang mengarah untuk memposisikan organisasi bisnis bukan semata sebagai institusi sosial. Bahkan, dalam diri organisasi bisnis sebagai institusi ekonomi, di dalamnya ada dimensi tanggung jawab sosial yang mesti dipikul organisasi bisnis.

Godeke (2003: 2) menyebutkan ada beberapa faktor yang mempengaruhi perubahaan hubungan antara organisasi dan komunitasnya. Seraya menyatakan bahwa konsep-konsep Community Relation tradisional perusahaan tidak lagi bisa mencakup kegiatan operasi saat ini yang dilakukan berbagai perusahaan di seluruh dunia, Godeke menyatakan faktor-faktor tersebut adalah (1) Globalisasi sebagai akibat dari ekspansi yang mendunia, usaha swasta dan ekonomi pasar, (2) Peningkatan harapan konsumen khususnya dan masyarakat pada umumnya yang menginginkan dunia bisnis bisa dan seharusnya memenuhi kebutuhan-kebutuhan yang sebelumnya ditangani pemerintah, (3) Menguatnya masyarakat madani dan sektor LSM yang makin berdaya karena teknologi informasi dan mendapatkan kepercayaan publik, (4) Pengaruh meningkatnya gerakan lingkungan yang menekankan pada transparansi, keberlanjutan, akuntabilitas serta pelaporan yang berdasarkan transparansi, akuntabilitas, dan keberlanjutan, (5) Pasar dan tenaga kerja berbakat yang bergerak menuju pemberian hukuman bagi perusahaan-perusahaan yang mengabaikan masalah kemasyarakatan dan menghargai perusahaan-perusahaan yang makin hari makin banyak yang berusaha menjawab perubahan tersebut. Sejalan dengan itu, komunitas tidak lagi hanya dimaknai dengan lokalitas, melainkan juga sebagai struktur yang di dalamnya juga terjadi interaksi karena memiliki nilai-nilai dan kepentingan yang sama serta manfaatnya bisa dirasakan kedua belah pihak. Community Relation demi keberlangsungan organisasi dan komunitasnya dalam bentuk tanggung jawab sosial.

Community Relation \& Community Development pada dasarnya adalah kegiatan Public Relation. Maka langkah-langkah dalam proses Public Relation mewarnai langkah-langkah dalam Community Relation \& Community Development. Public Relation di sini lebih dimaknai sebagai kegiatan organisasi dan bukan proses komunikasi yang dilakukan organisasi dengan publiknya. Kalau ada sedikit perbedaan dalam pendekatan pelaksanaan kegiatan, lebih disebabkan karena sifat kegiatan yang diselengarakan dalam Community Relation \& Community Development. Mengingat Community Relation \& Community Development berhadapan langsung dengan permasalahan sosial yang nyata yang dihadapi komunitas sekitar organisasi.

Satu prinsip yang hendak dikembangkan melalui kegiatan ini adalah mengembangkan hubungan bertetangga yang baik. Berbaik-baik dengan tetangga sungguh sangat besar manfaatnya. Pabrik atau perusahaan yang ada akan dipandang oleh tetangganya, yakni publik atau komunitas, seperti miliknya sendiri. Ada keinginan untuk turut menjaga dan melindunginya, karena kegunaan keberadaan perusahaan atau pabrik itu dirasakan oleh publik atau masyarakat sekitarnya. Wajar bila Jerold mendefenisikan Community Relation \& Community Development sebagai "program pengembangan komunitas yang melalui berbagai upaya untuk kemaslahatan (keberlangsungan) bersama bagi organisasi dan komunitas”. Meski DeMartinis (2004:1) menjelaskan Community Relation hanya sebagai "cara berinteraksi dengan berbagai publik yang saling terkait dengan operasi 
organisasi”. Selanjutnya dijelaskan DeMartinis bahwa komunitas itu mencakup klien, lingkungan, pejabat, publik, lembaga pemerintahan dan lembaga lain. Namun konsep DeMartinis tentang komunitas sama dengan konsep Hallahan (2003), yang menunjukkan bahwa sesungguhnya apa yang dinamakan publik dalam Public Relation adalah komunitas.

Kegiatan Community Relation \& Community Development juga merupakan kegiatan tanggung jawab Social Corporate. Wajar bila berbagai perusahaan di Indonesia kini sudah menjalankan tanggung jawab sosialnya itu dalam bentuk program dan kegiatan Community Relation. Ada yang memberikan beasiswa, memberikan bantuan buku, merehabilitasi lingkungan hidup, atau membantu usaha kerajinan masyarakat. Setidaknya, ada 3 bidang program Community Relation, yaitu pendidikan, kesehatan, dan seni budaya. Chambers, et al (2003:1) mendefenisikan tanggung jawab Social Corporate sebagai "melakukan tindakan sosial (termasuk lingkungan hidup) lebih dari batasan-batasan yang dituntut peraturan perundang-perundangan.” Natufe (2001:9) mendefenisikan tanggung jawab Social Cooperate sebagai "komitmen berkelanjutan kalangan bisnis untuk berprilaku etis dan memberikan sumbangan pada pembangunan ekonomi sekaligus memperbaiki mutu hidup angkatan kerja dan keluarganya serta komunitas lokal dan masyarakat secara keseluruhan.”

Teknik atau jenis kegiatan Community Relation. Pengembangan ekonomi komunitas merupakan jenis kegiatan Community Relation yang memberikan manfaat bagi komunitas dan organisasi. Komunitas yang kemampuan ekonominya berkembang dengan bantuan organisasi bisnis, tentu akan meningkatkan derajat kesejahteraannya, pengembangan kewirausahaan atau agribisnis akan mengembangkan penciptaan lapangan kerja oleh komunitas untuk komunitas sehingga organisasi tidak terbebani harus mempekerjakan komunitas sekitar organisasi yang keterampilannya tidak memenuhi kualifikasi yang diperlukan.

Konsep ideal hubungan kemitraan antara usaha besar dan usaha kecil dan menengah bisa menjadi contoh implementasi Community Relation di Indonesia. Meski dalam praktiknya membangun kemitraan itu sendiri disindir lebih banyak memberi manfaat untuk usaha besar dibandingkan dengan usaha kecil, setidaknya secara konseptual pengembangan hubungan kemitraan itu bisa dipandang sebagai wujud kegiataan Community Relation yang dijalankan organisasi bisnis di Indonesia.

\section{METODE PENELITIAN}

Metode penelitian yang digunakan dalam penelitian ini adalah metode pendekatan kualitatif dan studi kasus. Untuk tipe penelitian yang dipilih adalah studi kasus. Studi kasus adalah metode riset yang menggunakan berbagai sumber data (sebanyak mungkin data) yang bisa digunakan untuk meneliti, menguraikan, dan menjelaskan secara komprehensif berbagai aspek individu, kelompok, suatu program, organisasi atau peristiwa secara sistematis. Oleh karena itu, periset dapat menggunakan wawancara mendalam, observasi partisipan, dokumentasi-dokumentasi, rekaman, bukti-bukti fisik, dan lainnya (ibid, 2007:66). Untuk riset dalam penelitian ini, peneliti menggunakan tipe studi kasus deskriptif.

Nara sumber dalam penelitian ini adalah sebagai berikut (1) General Manager, adalah orang yang memiliki tanggung jawab terhadap seluruh bagian / fungsional pada suatu perusahaan atau organisasi. Tugasnya memimpin beberapa unit bidang fungsi pekerjaan yang mengepalai beberapa atau seluruh Manager fungsional dan melaporkan hasilnya kepada CEO; (2) Public Relation Manager, adalah orang berkerja sebagai penghubung informasi antara organisasi dengan internal (karyawan) dan eksternal (publik). Public Relation merupakan orang yang ahli di bidang komunikasi dan bertanggung jawab untuk pembentukan citra dari PT Indah Kiat Pulp and Paper; (3) Perwakilan dari setiap sekolah (kepala sekolah dan murid) adalah perwakilan dari setiap sekolah yang ikut merasakan kegiatan CSR 
dari PT Indah Kiat Pulp and Paper; (4) Perwakilan dari pemerintah (Kepala Depdiknas) adalah orang yang menjadi perwakilan dari pemerintah yang ikut serta merasakan CSR dari PT Indah Kiat Pulp and Paper Serang. Nara sumber tersebut adalah nara sumber yang secara langsung terlibat dalam pemberian informasi dalam penelitian ini.

Teknik pengumpulan data yang digunakan dalam penelitian ini adalah wawancara mendalam (depth interview). Menurut Guba dan Lincon (1981:179), maksud menggali lebih dalam untuk keperluan (1) Klarifikasi, jika pewawancara memerlukan lagi informasi tentang hal yang dipersoalkan sebelumnya; (2) Kesadaran Kritis, jika responden ditanyakan untuk memutuskan atau lebih kritis lagi; (3) Penjelasan, jika pewawancara memerlukan informasi mengenai berbagai aspek atau dimensi suatu pertanyaan; (4) Refokus, jika responden ditanya untuk mengaitkan, membandingkan atau mempertentangkan jawabannya dengan topik atau ide, untuk memikirkan pemecahan hubungan sebab akibat; (5) Informasi, tentang intensitas perasaan responden, pertanyaan yang diajukan berkisar pada bentuk "pertanyaan pribadi”, pertanyaan "alasan mengapa”, sampai pada pertanyaan "intensitas"; dan (6) Kepustakaan, peneliti memperoleh data melalui dokumentasi data yang sudah ada yang bisa didapatkan dari profil perusahaan, internet, buku-buku mengenai hal-hal yang berhubungan dengan penelitian.

\section{Teknik Analisis}

Analisis data kualitatif digunakan bila data-data yang terkumpul dalam riset adalah data kualitatif. Data kualitatif dapat berupa kata-kata, kalimat-kalimat atau narasi-narasi, baik yang diperoleh dari wawancara mendalam maupun observasi. Tahap analisis data memegang peran penting dalam riset kualitatif, yaitu sebagai faktor utama penilaian kualitas tidaknya riset, artinya kemampuan periset membuat makna kepada data merupakan kunci apakah data yang diperolehnya memenuhi unsure validitas atau tidak. Dalam penelitian ini peneliti analisis domain, menurut Bungin (2001:196198), teknik analisis domain digunakan untuk menganalisis gambaran-gambaran objek riset secara umum atau menganalisis di tingkat permukaan, namun relatif utuh tentang objek riset tersebut. Teknik ini bertujuan mendapatkan gambaran seutuhnya dari objek yang diriset, tanpa harus membuat rincian secara detail unsur-unsur yang ada dalam keutuhan objek tersebut.

\section{HASIL DAN PEMBAHASAN}

\section{Analisis Pembahasan}

Pada penelitian tentang Kontribusi Perusahaan Pulp and Paper Serang bagi kehidupan masyarakat dan pemerintah daerah melalui peran serta Public Relation, penulis menggunakan analisis SOSTAC, yaitu sebagai berikut:

Bidang pendidikan rutin. Kondisi sumber daya manusia yang dimikian kurang memadai dan tidak memiliki skill tentunya berpengaruh besar terhadap perkembangan di wilayah Kabupaten Serang pada umumnya dan perusahaan di wilayah kabupaten Serang pada khususnya. Oleh karena itu, PT Indah Kiat membentuk suatu sinergi yang saling berhubungan antara perusahaan, karyawan, dan masyarakat sekitar yang apabila digambarkan dalam segitiga, sebagai berikut. 


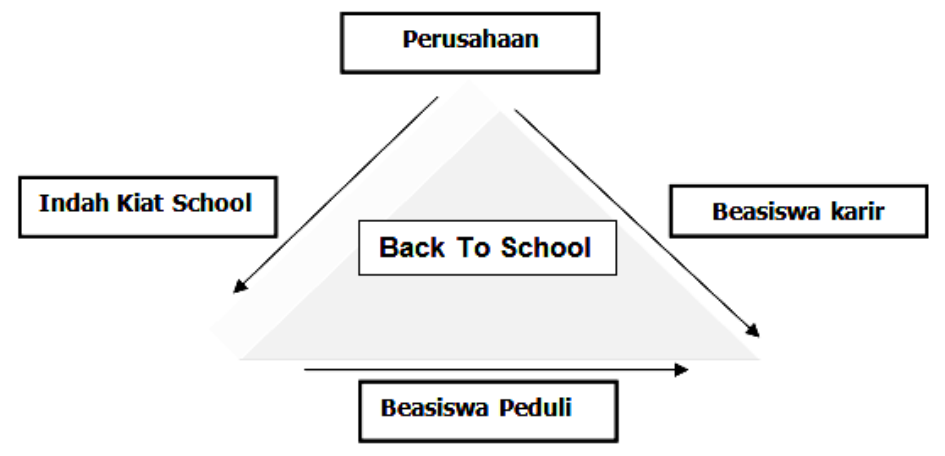

Sumber: doc. IKPP, 2007

Gambar 2 Segitiga Pendidikan Berkesinambungan

"Back To School” merupakan serangkaian program pendidikan yang dijalankan oleh PT Indah Kiat Serang sebagai wujud kepedulian perusahaan terhadap masyarakat sekitar. Hal ini diwujudkan sebagai bagian dari program Corporate Social Responsibility. Beasiswa karir merupakan wujud kepedulian karyawan terhadap masyarakat. Di dalam ketiga program yang bersinergi ini, terdapat satu makna, yakni Kembali ke Sekolah (Back to School). Pertama, program Beasiswa Peduli. Menurut pernyataan Bapak Danny selaku staf Public Relation, "Program beasiswa peduli merupakan program untuk education mereka mengadakan program ini karena melihat kondisi ekonomi masyarakat yang masih rendah. Perbedaan program beasiswa ini dengan perusahaan lain adalah adanya rasa empati dari karyawan sendiri untuk menyumbang memberi dana pendidikan dari gaji mereka dengan sukarela, bukan dari perusahaan sendiri”.

Kedua, program Beasiswa Karir. Sebagai industri kertas non padat karya, ketersediaan tenaga kerja siap pakai di PT Indah Kiat Serang masih belum memadai, khususnya dari masyarakat Kabupaten Serang. Menurut peryataan Bapak Danny selaku staf Public Relation, "Sayangnya komunitas lokal yang merupakan SDM masyarakat Banten tidak mempunyai jenjang pendidikan yang lebih tinggi karena tingkat ekonomi yang masih rendah, mereka rata-rata hanya lulusan SD-SMP. Permasalahan lain adalah menyangkut tuntutan dari masyarakat sekitar yang ingin berkerja di PT Indah Kiat Serang, namun tidak memiliki pendidikan yang cukup sehingga dengan melihat situasi seperti itu, perusahaan memberikan beasiswa karir bagi siswa atau siswi terbaik di Kecamatan Kragilan untuk mengenyam pendidikan di Akademi Teknologi Pulp \& Kertas (ATPK) Bandung”. Ini merupakan beberapa poin mengenai beasiswa karir, yaitu (1) Program Beasiswa Karir di berikan untuk melanjutkan studi Diploma 3 tahun di Akademi Teknologi Pulp \& Kertas (ATPK) Bandung; (2) Program dimulai tahun 2001 dan setiap tahunnya memilih 3 siswa atau siswi terbaik dari Kecamatan Kragilan. Semula beasiswa hanya berlaku bagi siswa yang berdomisili di Kecamatan Kragilan, mulai tahun 2005 dikirim sebanyak 4 siswa atau siswi lulusan terbaik dari 6 Kecamatan (Kecamatan Kragilan, Tirtayasa, Pontang, Carenang, Tanara, dan Ciruas); (3) Sesuai dengan tahapan manajemen Public Relation, staf Indah Kiat Pulp and Paper, Tbk. Serang Mill telah berkerja sama dengan Dinas Pendidikan Kabupaten Serang untuk mengadakan kerja sama untuk mensurvey pencarian informasi minat siswa dan kebutuhan perusahaan. Setelah data terkumpul, mereka mengadakan rapat internal dan membentuk kepanitiaan yang terdiri atas tiga seksi, yaitu seksi Public Relation, seksi Job Training (yang bertugas mengurus manajemen pengadaan test untuk peserta beasiswa karir) dan Personalia (bertugas untuk mengatur hak-hak dan kewajiban yang berlaku untuk peserta beasiswa karir). Setelah selesai menempuh pendidikan di ATPK, peserta akan diberi kesempatan untuk magang di PT Indah Kiat Pulp and Paper. Jika pekerjaannya bagus, dia akan dikontrak selama 6 bulan sebelum ditetapkan menjadi karyawan tetap. 
Ketiga, program IKS (Indah Kiat School). Pada saat baru mulai beroperasi, yakni pada tahun 1992 PT Indah Kiat Serang merekrut sebagian besar tenaga kerja dari masyarakat sekitar dan masyarakat Serang pada umumnya. Pada saat itu, masih sedikit yang mengenyam pendidikan hingga lulus SMA. Padahal dengan SDM karyawan yang tinggi akan juga berpengaruh terhadap keberlangsungan kemajuan perusahaan itu sendiri. Menurut Peryataan Bapak Danny selaku staf Public Relation, "dalam rangka membentuk pola pikir dan menambah wawasan karyawan, perusahaan menyelengarakan pendidikan formal setara SMP dan SMA bagi karyawan atau karyawati melalui program pendidikan paket B (setara SMP) dan Paket C (setara SMA) melalui pendirian Indah Kiat School (IKS). Untuk itu mereka melaksanakan program pengembangan SDM karyawan perusahaan melalui Program Indah Kiat School (IKS). Sebagian besar siswa yang mengikuti pendidikan IKS adalah karyawan yang berasal dari Serang”.

Pelaksanaan program IKS dilaksanakan seperti sekolah-sekolah pada umumnya. Tahun ajaran 2003-2004 merupakan tahun pertama penyelenggaraan IKS yang membuka 4 kelas untuk kelas 1 Paket C dan 2 kelas untuk kelas 1 Paket B. untuk kurikulum Paket B meliputi 6 mata pelajaran, yaitu PPKN, Bahasa Indonesia, Matematika, IPA, IPS, dan Bahasa Inggris. Kurikulum Paket C kelas 1 dan 2 meliputi 8 mata pelajaran, yaitu PPKN, Bahasa Indonesia, Bahasa Inggris, Matematika, Sosiologi, Kimia, Ekonomi, dan Tata Negara; ditambah 2 mata pelajaran tambahan, yakni keterampilan dan sikap mental untuk paket B dan paket C. Staf PR tiap tahunnya mensurvei kebutuhan perusahaan dan pencarian data karyawan lulusan dibawah SMA, setelah terkumpul, staf PR akan berkoordinasi dengan Dinas Pendidikan Nasional kabupaten untuk mengurus perijinan sekolah dan mencari tenaga pengajar bagi IKS. Setelah karyawan menyelesaikan sekolah di IKS, staf Public Relation akan membuat laporan ke Dinas Pendidikan Nasional kabupaten dan seksi atau departemen. Bagi karyawan yang memiliki hasil yang sangat baik, akan dipromosikan jabatannya. Biasanya pada rapat internal pencarian data karyawan, staf Public Relation mengadakan sekaligus evaluasi atas program IKS di tahun sebelumnya, apakah ada kekurangan yang harus diperbaiki dsb.

Keempat, program Job Training / Kerja Praktek. PT Indah Kiat Pulp and Paper menyadari bahwa salah satu publik mereka berasal dari institusi pendidikan terutama dari para pelajar, maka untuk terus menjembatani hubungan yang harmonis dan untuk mengenalkan perusahaan lebih jauh, pihak perusahaan mengadakan program job training. Pada program ini, Public Relation tidak memiliki kapasitas yang besar karena yang bertanggung-jawab penuh adalah seksi Job Training. Dengan demikian, staf Public Relation tidak menjalani manajemen Public Relation. Biasanya Public Relation hanya meminta peserta magang kepada seksi Job Training, dan Job Training pun mencarikan dari peserta yang sudah mendaftar untuk magang, staf Public Relation akan memberikan nilai evaluasi yang diberikan kepada peserta dan seksi Job Training. Kelima, program Tali Kasih Pendidikan. Menurut peryataan Bapak Danny selaku staf Public Relation, "Program Tali Kasih Pendidikan merupakan program Beasiswa Tali Kasih Pendidikan bagi anak-anak almarhum karyawan atau karyawati. Hal ini didasari oleh adanya keinginan baik perusahaan untuk tetap menjalin hubungan yang baik dengan keluarga almarhum. Program ini diprakasai oleh staf Public Relation sehingga tugas ini menjadi tanggung-jawab sepenuhnya staf Public Relation”. Ketika mengetahui informasi mengenai adanya karyawan meninggal, staf Public Relation pun mengobservasi data karyawan tersebut dan mencari apakah si karyawan tersebut mempunyai tanggungan (dalam hal ini anak). Jika ada, maka perusahaan akan meneruskan membiayai pendidikan anak karyawan sampai tingkat perguruan tinggi dengan jumlah nominal bantuan yang sudah ditetapkan. Karena program ini baru berjalan di tahun ini, maka staf Public Relation belum melakukan evaluasi program. Namun staf Public Relation mengharapkan adanya peningkatan jumlah sumbangan tiap tahunnya.

Program Non Rutin, di antaranya adalah (1) Pembangunan sekolah. Sampai saat ini, PT Indah Kiat Pulp \& Paper, Tbk. Serang sudah memberikan bantuan pembangunan gedung SD sebanyak 2 unit SD, yakni SDN Kragilan VI dan SDN Kragilan IV, dengan membuat fasilitas lengkap seperti ruang guru, perpustakaan, lapangan olah raga, UKS, tempat tinggal guru, dan penjaga sekolah; (2) Bantuan sarana dan prasarana. Selanjutnya, dalam menanggapi saran tersebut, staf PR mengadakan rapat, guna 
membicarakan bantuan seperti apa dan bagaimana bentuknya itu diberikan. Biasanya bantuan sarana dan prasarana sekolah yang diberikan antara lain tas sekolah, seragam, buku tulis, kipas angin, peralatan olahraga, alat-alat kebersihan dan lain sebagainya. Menurut peryataan Bapak Danny selaku staf Public Relatios, "pada awal tahun ini, staf Public Relation telah memberikan buku tulis kepada anak-anak SD di 7 Kecamatan di Serang”; (3) Kunjungan mahasiswa dan pelajar. Program ini merupakan program yang memberikan kesempatan kepada kalangan pelajar dan mahasiswa untuk melakukan kunjungan di perusahaan. Staf Public Relation merupakan pembuka ruang dengan seksi yang mewakili perusahaan dalam acara kunjungan. Setelah menerima informasi adanya sekolah yang akan melakukan kunjungan, staf Public Relation rapat membicarakan siapa yang akan mewakili dan draft acara apa yang akan dilakukan selama kunjungan; (4) Mengadakan lomba kebersihan. Menurut peryataan Bapak Danny selaku staf Public Relation, "dalam mengadakan acara ini, jauh sebelumnya staf Public Relation membicarakan mengenai implementasi Lomba Kebersihan Tingkat SDN Sekecamatan Kragilan di mana lomba ini merupakan salah satu program bentuk kepedulian PT Indah Kiat Pulp and Paper Serang, khususnya dalam bidang pendidikan”.

Selain itu, perusahaan berupaya untuk menumbuhkan kesadaran bersih sejak usia dini di kalangan pelajar dan merupakan langkah awal menciptakan Sumber Daya Manusia yang handal atau berdisiplin sejak masa usia sekolah dasar. Hasilnya dalam jangka pendek, lingkungan sekolah lebih terawat dan bersih serta sehat. Perusahaan pun bisa mendapat pandangan positif yang bisa mempengaruhi image perusahaan. Program ini akan dievaluasi staf Public Relation dalam rapat evaluasi tahunan yang besar.

Tabel 1 Analisis SOSTAC Hasil Penelitian

\begin{tabular}{|c|c|}
\hline Dimensi & Hasil Penelitian \\
\hline Situation (Situasi) & $\begin{array}{l}\text { Bagi PT Indah Kiat Plup \& Paper Tbk. Serang-Banten, sifat charity (amal) } \\
\text { dengan memberikan bantuan mungkin dipandang memadai untuk membangun } \\
\text { hubungan bertetangga yang baik. Dan dipandang memadai untuk membangun } \\
\text { hubungan bertetangga yang baik. Tetapi, bagi masyarakat sekitar perusahaan, } \\
\text { tentu bukan sekedar itu, bertetangga baik itu bisa juga dalam bentuk memberi } \\
\text { prioritas bagi warga sekitar untuk berkerja di perusahaan. Hubungan } \\
\text { perusahaan dan masyarakat sekitar secara keseluruhan berada pada kondisi } \\
\text { yang dinamis }\end{array}$ \\
\hline Objective (Objektif) & $\begin{array}{l}\text { Menciptakan hubungan yang harmonis antara perusahaan dengan masyarakat } \\
\text { sekitar; } \\
\text { Meningkatkan citra perusahaan; } \\
\text { Membantu masyarakat sekitar dalam hal pendidikan yang dilakukan secara } \\
\text { bekelanjutan (diberikan setiap } 6 \text { bulan sekali). }\end{array}$ \\
\hline Strategy (Strategi) & $\begin{array}{l}\text { Dengan melakukan kegiatan Community Development \& Community Relation } \\
\text { secara berkelanjutan dalam bidang pendidikan sehingga membantu masyarakat } \\
\text { sekitar dalam hal mengenyam pendidikan dan pemerintah daerah dalam hal } \\
\text { meningkatkan mutu pendidikan di daerah Kragilan. }\end{array}$ \\
\hline Tactic (Taktik) & $\begin{array}{l}\text { Dengan berbagai cara seperti: } \\
\text { Meningkatkan program Community Development \& Community Relation; } \\
\text { Menjalin kerjasama dengan berbagai eleme masyarakat dalam setiap kegiatan } \\
\text { keagamaan, kesehatan, pendidikan, dan peringatan Hari Kemerdekaan; } \\
\text { Meningkatkan hubungan baik dengan unsur-unsur pemerintah atau LSM dari } \\
\text { tingkat provinsi sampai desa; } \\
\text { Memberikan peluang usaha dengan peningkatan program pemberdayaan } \\
\text { masyarakat; } \\
\text { Berkerja sama dengan Dinas Pendidikan dalam hal beasiswa. Untuk pemberian } \\
\text { beasiswa di daerah Kragilan, yaitu di } 6 \text { Kecamatan, yaitu Kecamatan Kragilan, } \\
\text { Tirtayasa, Pontang, Carenang, Tanara, dan Ciruas. }\end{array}$ \\
\hline
\end{tabular}




\begin{tabular}{|c|c|}
\hline Action (Aksi) & $\begin{array}{l}\text { Aksi yang dilakukan dalam bidang pendidikan, yaitu program IKS (Indah Kiat } \\
\text { school), Beasiswa Peduli, Beasiswa Karir, Program Job Training, Program Tali } \\
\text { Kasih Pendidikan, dan Non Rutin (pembangunan sekolah, bantuan sarana dan } \\
\text { prasarana, kunjungan mahasiswa, lomba kebersihan) }\end{array}$ \\
\hline Control (Kontrol) & $\begin{array}{l}\text { Kontrol yang dilakukan, yaitu pengumpulan fakta, pendefinisian permasalahan, } \\
\text { perencanaan program, aksi dan komunikasi, evaluasi }\end{array}$ \\
\hline
\end{tabular}

\section{SIMPULAN}

Bidang Public Relation adalah suatu bidang yang sangat luas menyangkut hubungan dengan berbagai pihak. Public Relation tidak sama dengan sekedar relation, meskipun personnel relation mempunyai peranan yang sangat penting dalam menjaga citra perusahaan. Public Relation dilihat dari konteks perkembangan ilmu-ilmu sosial, khususnya ilmu komunikasi, merupakan bidang yang sangat membantu dalam proses kerja manajemen dalam sebuah perusahaan. Kegiatannya berkaitan erat dengan pembinaan dan pengembangan hubungan yang harmonis antara perusahaan dengan masyarakat atau publiknya. Eksistensi dan peranannya sangat diperlukan terutama untuk mengatur arus informasi ke dalam maupun ke luar, memonitor opini atau tanggapan public terhadap perusahaan, serta menganalisis dan mengolah berbagai data untuk disampaikan kepada pemimpin perusahaan sebagai acuan dalam perumusan dan penyempurnaan kebijakan perusahaan.

Terkait dengan pelaksanaan praktek kerja di bagian Public Relation, maka kesimpulan yang didapat adalah sebagai berikut (1) Berdasarkan fakta-fakta yang ditemukan di lingkungan perusahaan, maka perusahaan berkewajiban membangun masyarakat sekitar melalui program CSR sebagai program yang penting didasari oleh tanggung jawab sosial perusahaan; (2) Peran Public Relation secara umum dalam menjalankan fungsinya sebagai Public Relation sama dengan perusahaanperusahaan yang memiliki seksi atau divisi Public Relation, hanya saja letak perbedaannya, yakni letak hierarki seksi Public Relation ini berbeda, masih di bawah seksi dan letaknya dibawahi oleh Divisi Humas. Hal ini menunjukkan bahwa walaupun staf Public Relation telah melakukan tugas untuk memanajerialkan kegiatan Public Relation, mereka belum berada di jajaran Top Management; dan (3) Dilihat dari berbagai aktivitas Community Relation yang telah dilaksanakan, menurut prakteknya, kegiatan-kegiatan tersebut banyak yang berdasarkan charity dan pemberdayaan masyarakat. Kegiatan-kegiatan tersebut, antara lain pendidikan dilaksanakan melalui program beasiswa, kemitraan dengan berkerjasama dengan LSM forklift, Koperasi Eka Kiat Sari, dan FK LKMD untuk memberdayakan pemuda sekitar.

Dengan demikian, secara general pengimplementasian Community Social Responbility yang dijalankan perusahaan sudah berjalan dengan baik, salah satunya dibuktikan dengan penghargaan ISO 14001 dan ISO 9001. Kegiatan yang dilakukan cukup representatif terhadap prinsip-prinsip CSR dan unsur-unsur kepentingan komunitas menurut Cutlip Center.

Saran akademis yang diberikan adalah sebagai berikut. Berdasarkan hasil pengamatan yang dilakukan oleh praktisi di Humas PT Indah Kiat Pulp \& Paper Tbk. Serang-Banten, terutama kegiatan Community Development \& Community Relation, pada saat pelaksanaan masih mengalami hambatan. Oleh karena itu, praktikan memberikan beberapa saran yang diharapkan dapat menunjang keberhasilan dari tugas dan fungsi Public Relation atau Humas di antaranya adalah (1) Mengingat begitu pentingnya Public Relation atau Humas dalam menciptakan saling pengertian, pemahaman, minat dan dukungan dari berbagai pihak yang menentukan keberhasilan perusahaan serta tanggung jawab atas terpeliharanya citra perusahaan serta bertanggung jawab atas terpeliharanya citra perusahaan yang baik 
di mata publik atau masyarakat, maka perlunya penempatan Public Relation pada posisi puncak dan kewenangan yang lebih luas, agar Public Relation atau Humas dalam menjalankan fungsi dan peranannya bisa lebih maksimal dengan harapan dapat menunjang keberhasilan program-program yang dirancang oleh Humas atau Public Relation sehingga kegiatan CSR bisa berjalan dengan baik; (2) Mengoptimalkan penggunaan media internal organisasi agar pesan yang diterima dapat menjadi efektif dan lebih cepat untuk diterima guna meningkatkan aliran informasi yang ada di perusahaan.

Berikut adalah saran praktis dari penelitian yang sudah dilakukan, yaitu (1) Sebaiknya perusahaan menambah personel Public Relation, untuk meningkatkan kegiatan Social Responsibility dalam menjalankan tugas, agar tidak terjadi tumpang tindih pekerjaan oleh satu orang antara pekerjaan kantor dan pekerjaan lapangan; (2) Sebaiknya perusahaan dalam penempatan personel yang akan menangani kegiatan Community Development \& Community Relation harus ditangani dengan orangorang yang benar-benar berkompeten dengan kemampuan yang sesuai dan andal dalam bidang ini; (3) Karyawan merupakan aset berharga bagi perusahaan. Oleh karenanya, ide atau gagasan dari karyawan hendaknya didengar dan diwujudkan dengan pertimbangan ataupun penetapan kebijakan; (4) Menambah staf Public Relation dari karyawan sendiri; (5) Perlu adanya pembaharuan dalam media komunikasi internal sesuai dengan teknologi saat ini, contohnya pihak perusahaan dapat menjadikan Yahoo Messenger (YM) ataupun Blackberry Messenger sebagai salah satu kebijakan komunikasi internal yang wajib dilakukan oleh para karyawan.

\section{DAFTAR PUSTAKA}

Alifahmi, H. (2005). Sinergi komunikasi pemasaran, Jakarta: Quantum Business and Management.

Anggoro, L. (2001). Teori dan profesi humas serta aplikasinya di Indonesia, Jakarta: Bumi Aksara.

Cutlip, S., and Center, A. (1988). Public relation, Jakarta: PT Bumi Aksara.

Davis, A. (2005). Everything you should know about public relation, Jakarta: PT Elex Media Komputindo.

Frida, K. (2002). Dasar-dasar humas, Jakarta: Lembaga Penelitian UMM.

Iriantara, Y. (2004). Community relation konsep dan aplikasinya, Bandung: Simbiosa Rekatama Media.

Iriantara, Y., and Surachman, Y.A. (2006). Public relation writing, Bandung: Simbiosa Rekatama Media.

Jefkins, F. (2004). Public relation, edisi kelima, Jakarta: Erlangga.

Kensali, R. (1994). Manajemen public relation, Bandung: PT Pustaka Utama Grafiti.

Kriyanto, R. (2007). Teknik praktik riset komunikasi, Jakarta: Kencana.

McNamara, C. (2002). Public relation, Jakarta: PT Bumi Aksara.

Moi, A. (2006). Menjadi public relation yang andal, Yogyakarta: Dolphin Books.

Prisgunanto, I. (2006). Komunikasi pemasaran, Bogor: Ghalia Indonesia. 
Rumanti, M.A. (2004). Dasar-dasar public relation, Jakarta: Grasindo.

Ruslan, R. (2005). Metode penelitian public relation dan media komunikasi, Jakarta: PT Raja Grafindo Persada.

Setyodarmadjo, S. (2003). Public relation: Pengertian, fungsi dan peranannya, Surabaya: Pepirus.

Soemirat, S., dan Ardianto, E. (2004). Dasar-dasar public relation, Bandung: PT Rosdakarya.

Thomas, C.C. (1990). Public relation, Jakarta: PT Bumi Aksara.

Tondowidjojo, J. (2004). Dasar dan arah public relation, edisi kedua, Jakarta: Grasindo.

Wasesa, S.A. (2005). Strategi public relation, Jakarta: PT Gramedia Pustaka Utama. 